\title{
Protective Effects of Green Tea and Moringa Leave Extracts and Their Bio-Yoghurts against Oxidative Effects of Lead Acetate in Albino Rats
}

\author{
Mohamed G El-Ziney*, Enaam S Shokery, Assma H Youssef and Reda E Mashaly \\ Faculty of Agriculture, El-Shatby, Department of Dairy Science and Technology, Alexandria Egypt.
}

Received: April 21, 2017; Accepted: May 05, 2017; Published: May 15, 2017

*Corresponding author: Mohamed G. El-Ziney, Associate Professor of Dairy Science and Technology, Laboratory of Functional Foods, PO Box 21454, Alexandria, Egypt, Tel/Fax: 02-3-5925805; E-mail: elziney@yahoo.com

\begin{abstract}
Background: Health benefits of designed functional foods using dairy fermented products in co-production with medicinal herbs are under comprehensive investigations. Yoghurt has triggered a functional food revolution while green tea and Moringa oleifera represent precious source of high content of various types of antioxidants and micronutrients. Oxidative stress and lipid peroxidation are suggested mechanisms involved in lead toxicity. The aim of present study was to assess protective effects of green tea and moringa leave extracts and their bio-yoghurts against lead acetate-induced oxidative stress in male rats by following liver weight and enzymes and lipids profile.
\end{abstract}

Materials and Methods: A total of 42 male albino rats were divided into seven groups. Group I was left as control; fed on standard diet only and lead acetate free water. Group II was fed on standard diet and drink Pb-Ac contaminated water (0.3\%). Group III was fed on standard diet, drink $\mathrm{Pb}$-Ac contaminated water and orally injected with $882 \mathrm{mg} / \mathrm{kg}$ of rat body weight extract of green tea. Group IV was fed on standard diet, drink $\mathrm{Pb}$-Ac contaminated water and orally injected with $882 \mathrm{mg} / \mathrm{kg}$ of rat body weight extract of Moringa oleifera leaves. Group V was fed on standard diet, drink Pb-Ac contaminated water and orally injected with $15 \mathrm{~g}$ of yoghurt. Group VI was fed on standard diet, drink Pb-Ac contaminated water and orally injected with $15 \mathrm{~g}$ of green tea yoghurt $(88.2 \mathrm{mg} / \mathrm{kg}$ rat wt green tea extract). Group VII was fed on standard diet, drink lead acetate (PbAc) contaminated water and orally injected with $15 \mathrm{~g}$ of moringa yoghurt $(88.2 \mathrm{mg} / \mathrm{kg}$ rat wt moringa leaves extract). Absolute and relative liver was followed after five weeks. Liver enzymes were determined including Alanine Aminotransaminase (ALT) and Aspartate Aminotransaminase (AST). Lipid profile of rat blood serum was measured including Total Cholesterol (TC), Triglyceride (TG), Low Density Lipoprotein (LDL), and High Density Lipoprotein (HDL)

Results: The rat liver weight of lead intoxicated group (G II) was increased significantly in compared to the rest of tested groups. The order of relative liver weight of rat treated groups was as follow: GII $>\mathrm{GV}>\mathrm{GVI}>\mathrm{GVII}>\mathrm{GIII}>\mathrm{GIV}>\mathrm{GI}$. The rats fed on green tea or Moringa oleifera extracts and their bio yoghurt showed a significant decrease in the ALT and AST levels compared to Pb-Ac intoxicated rat (GII). Meanwhile, enzymes level was improved at less extend in rat group fed with plain yoghurt (GV). Moringa leaves extract alone or in yoghurt had a superior lowering effect on TC and LDL compared with green tea extract. Moreover, a similar effect was observed of both plant extracts on TG and HDL.

Conclusion: Green tea and Moringa oleifera extracts alone or in bio-yoghurts were able to provide protective effects against oxidative stress induced by lead acetate. Also, plain yoghurt had a relief effect but at lesser extent.

Keywords: Green tea; Moringa oleifera; Yoghurt; Lead acetate; Liver enzyme; Cholesterol Heart Symbol, with more success in meeting nutrition recommendations.

\section{Introduction}

Fermented dairy foods are progressively become more and more popular as a result of numerous of associated health benefits. Beside the contents of high-quality protein, and bioavailability calcium, it is recognized as powerful functional foods. Fermented dairy products are fine sources of highly digestible nutrients particularly for individuals suffer from food allergy like lactose intolerance, active and antioxidant components $[1,2]$ and beneficial probiotic intestinal inhabitant organisms [3]. Recent meta-analyses of cohort studies have shown that dairy; mainly the ferments, consumption is related with a lowering risk of heart diseases, high blood pressure, stroke and diabetes [4-7].

Formulation of novel dairy products using medicinal herbs or its extracts is very interested area for food industries to meet the health conscious consumers' demand to bring more functionality values and flourish the flavor of the new products.

Green tea (Camellia sinensis var. Sinensis) is second only to drinking water as the most used beverage on the earth. Health benefits of green tea are manly related with its antioxidant contents [8]. Beside of the proposed health advantages, green tea is highly appreciated due to its aroma and taste. The antioxidant properties are mainly anticipated to polyphenol content. A lot of studies concerning green tea extract have been directed at its possible anti-inflammatory, cardiovascular and anti-carcinogenic effects [9]. In responded to document health benefits of tea catchenis, new products have been developed with tea as an energetic ingredient such as tea beverages, ice creams, cereal and 
pet foods. It is reported that tea is produced with milk in different concentrations to order to enhance sensory characteristics however; tea herb is not regularly consumed with milk hence though new formula of green tea with soy and other milk products are increasing [10]. Implementation of green tea infusion during yoghurt production led to enhance the antioxidant capacity in final product and promote the growth of Lactobacillus spp. and $S$. thermophiles during fermentation [11]. Panelists appreciated cheddar cheese prepared with green tea extract while antiradical activity of cheese had increased significantly [12].

Moringa oleifera is a tropical tree with well recognized nutritional and medicinal properties. Moringa is consumed by humans throughout the century in diverse culinary ways [13] The leaves can be consumed fresh, cooked, or dried and stored for months without any major loss of its nutritional value [14].

Moringa leaves are an abundant source of polyphenols [16], flavonoids [17], minerals [18], alkaloids and proteins [19, 20]. The substances such as bioactive carotenoids, tocopherols and vitamin $\mathrm{C}$ showed health-promoting potential in maintaining a balanced diet and protecting against free-radical damage that might initiate many diseases [21]

Moringa or its extracts had been used to improve the nutritional quality of yoghurt, cottage cheese [22, 23], and bakery products with special reference to protein, fiber and minerals $[24,25]$. Several epidemiological studies have demonstrated that Moringa leaves exhibit anti-tumor, anti-inflammatory, antiulcer, anti-atherosclerotic and anti-convulsant activities [26-28].

Lead $(\mathrm{Pb})$ is a very strong oxidizing agent has been praised for its negative effects toward different body organs and their functions [29]. It is postulated that the key lead toxicity targets are the heme-biosynthesis enzymes, thiolcontaining antioxidants, glucose 6-phosphate dehydrogenase, superoxide dismutase, catalase, glutathione peroxidase, and antioxidant compounds like Glutathione (GSH). Even at low levels in bloodstream lead is able to decrease enzymes activity and stimulate generation of reactive free radicals species and intensification oxidative stress [30].

The present work aimed to evaluate the potential protective effects of green tea and moringa leaves extracts and their bio-yoghurt against the amelioration of lead induced oxidative stress in albino rats.

\section{Materials and methods}

\section{Plant materials and extraction}

Sri Lankan dried Green Tea Leaves (GTL) in tea bags were purchased from Alexandria local markets (Ahmad Tea Ltd., Winchester Road, Hampshire, UK). Moringa oleifera leaves (MOL) powder was purchased from Egyptian Scientific Association of Moringa, Cairo. The preparation of GLT and MOL extracts were basically prepared according to $[11,31]$ respectively. Plant leaves extract was prepared at a concentration of $10 \%(\mathrm{w} / \mathrm{w})$ in distilled water. For green tea extraction the mixture was heated and held at $90^{\circ} \mathrm{C}$ for 15 min then filtered through Whatman ${ }^{\circledR}$ no.
4. The extraction of moringa leaves was performed in distillation apparatus uses $300 \mathrm{~mm}$ graham condenser. The MOL in water was boiled and held for $10 \mathrm{~min}$. The aqueous extract stock solutions $(100 \mathrm{mg} / \mathrm{ml})$ were freshly prepared for each set of experiments and stored in dark at $4^{\circ} \mathrm{C}$ for up to 5 days.

\section{Yoghurt mixture and starter}

The composition of yoghurt blend was composed of $(\mathrm{w} / \mathrm{w})$ fresh homogenized full fat-milk (3.7\% fat), El-Gharbia collecting center (50\%), full cream milk powder (FCMP), Arla, Denmark (6.4\%), low heated-skim milk powder(SMP), Fonterra, New Zealand (2.5\%), whey protein concentrate (WPC), Al Troika, Turkey (1\%), stabilizer, Mefad, Egypt $(0.25 \%)$, gelatin, Gelnex, Brazil (0.1\%), plant extract (1\%) and sterilized distilled water $(38.75 \%)$. Yoghurt starter culture was thermophilic FD-DVS YoFlex $^{\circledR}$ (Chr. Hansen, Hoersholm, Denmark) which consisted of Lactobacillus delbrueckii subsp. bulgaricus and Streptococcus thermophiles and used according to manufacturer instruction.

\section{Yoghurt production}

Fresh homogenized full fat-milk (3.7\% fat) was mixed with FCMP, SMP and WPC at $60^{\circ} \mathrm{C}$ using Vorwerk ${ }^{\circledR}$ (Thermomix, France). Then solubilized gelatin and stabilizer were added. The final volume was completed with warmed water to produce standardized milk mixture. The solid content of the yoghurt mixture was around $15-17 \%$. The mixture was heated at $90-95^{\circ} \mathrm{C}$ for $10 \mathrm{~min}$. then the blend is homogenized to mix all ingredients thoroughly and improve yogurt consistency. The standardized milk mixture was cooled to $42-45^{\circ} \mathrm{C}$ and divided into three portions. The first two milk portions were mixed with extract stock solutions of green tea and moringa at final concentration of $1.0 \%(\mathrm{w} / \mathrm{w})$. Subsequently, the milk mixtures were inoculated with the thermophilic FD-DVS YoFlex ${ }^{\circledR}$ starter then poured into $150-\mathrm{ml}$ sterile cups and incubated at $42-45^{\circ} \mathrm{C}$ for $4-6 \mathrm{~h}$ until firm coagula were formed ( $\mathrm{pH}$ of $=4.8$ ). Subsequently, yoghurts were partially cooled at room temperature before stored at $7{ }^{\circ} \mathrm{C}$ for 14 days while, it were used in animal feeding experiments.

\section{Chemicals}

Lead (II) acetate $(\mathrm{Ac}-\mathrm{Pb})$ were purchased from Sigma (Sigma, Chemical Co., USA) and prepared daily in drinking tap water at concentration of $0.3 \%(\mathrm{w} / \mathrm{v})$. Lead acetate was consumed by rats in diet as $=500 \mathrm{mg} / \mathrm{kg}$ diet daily for five weeks.

\section{Animals}

Forty two adult (7-8 weeks) male albino rats weighting 160-180 g were housed in plastic cages and kept in the animal house of Faculty of Agriculture -El Shatby campus, Alexandria University at room temperature $\left(25 \pm 2{ }^{\circ} \mathrm{C}\right)$, humidity of $60-70 \%$ , light/dark condition (12/12) and fed on commercial chow diet (ATMIDA).

\section{Animal experimental design}

After a week of acclimatization rats were divided into seven groups of 8 animals and assigned to specific diets for five weeks. 
Group I. (Negative control group): provided with drinking water free from $\mathrm{Pb} \mathrm{Ac}$ - and fed on normal standard chow diet.

Group II. (Positive control group): provided with $\mathrm{Pb}$ Ac- in drinking water $(0.3 \%)$ and fed on standard diet.

Group III. (Green tea extract (GTE) + Pb Ac- group): orally injected with green tea extract ( $882 \mathrm{mg} / \mathrm{kg}$ body wt/day) plus $\mathrm{Pb}$ Ac- in drinking water and fed on standard diet.

Group IV. (Moringa leaves extract (MLE+ Pb Ac- group): orally injected with moringa extract (882mg/ kg body wt/day) plus $\mathrm{Pb}$ Ac- in drinking water and fed on standard diet.

Group V. (Plain yoghurt (PY+ Pb Ac- group): orally injected with $15 \mathrm{~g}$ of plain yoghurt plus $\mathrm{Pb}$ Ac- in drinking water and fed on standard diet.

Group VI. (Green tee yoghurt (GTY) + Pb Ac- group): orally injected with $15 \mathrm{~g}$ of GTY (88.2mg green tea/ kg body wt/day) plus $\mathrm{Pb}$ Ac- in drinking water and fed on standard diet.

Group VII. (Moringa yoghurt (MY) + Pb Ac-group): orally injected with $15 \mathrm{~g}$ of GTY (88.2mg green tea/ kg body wt/day) plus Pb- Ac in drinking water and fed on standard diet.

After five weeks of feeding rats were exposed to diethyl ether, bled and sacrificed. Blood samples were collected in clean dry tube containing the anticoagulant substance, cooled $\left(4^{\circ} \mathrm{C}\right)$ for 2 hours and centrifuged ( $3000 \mathrm{x} \mathrm{g} / 20 \mathrm{~min}$ ). Serum samples were collected, labeled and stored at $-20^{\circ} \mathrm{C}$ until biochemical tests were carried out.

\section{Biochemical assays}

Liver Enzymes of alanine aminotransaminase (ALT/ GPT) and aspartate aminotransaminase (AST/GOT) were determined using Biosystems ${ }^{\circledR}$ colorimetric kits (Biosystems, Barcelona, Spain) according to the method described by Gella et al. [32]. Triglycerides (TG) in serum was determined using Reactivos $^{\circledR}$ enzymatic colorimetric kit (Reactivos $^{\circledR}$ GPL, Barcelona, Spain) according to the method described by Bucolo and David [33] and modified by Fossati and Prencipe [34]. Serum total cholesterol was determined using Reactivos ${ }^{\circledR}$ enzymatic colorimetric kit (Reactivos ${ }^{\circledR}$ GPL, Barcelona, Spain) according to Meiattini et al. [35]. High Density Lipoprotein cholesterol (HDL) was determined by participating of low and very density lipoprotein cholesterols (LDL; VLDL) with phosphotungstate and magnesium ion then HDL in the supernatant was measured by Biosystems ${ }^{\circledR}$ colorimetric kit (Biosystems, Barcelona, Spain) according to the method described by Grove [36]. LDL was calculated from the equation of Friedewald et al. [37] as follow

$$
\mathrm{LDL}=\text { Total cholesterol }-(\mathrm{HDL}+(\mathrm{TG} / 5))
$$

\section{Statistical analysis}

Data were analyzed using the SPSS statistics $® .13$ software. The Waller-Duncan k-ratio was used to determine the significance of the differences among treatments [38] at probability level of $\mathrm{P}<0.05$.

\section{Results and Discussions}

\section{Effect on liver weight}

The effect of fed lead acetate in drinking water $(=500$ $\mathrm{mg} / \mathrm{kg}$ body $\mathrm{wt}$ ) on the rats liver weight and the impact of oral administration of green tea or moringa leave extracts and their bio-yoghurts is shown in Table (1). The liver weights were increased significantly in all animals exposed to the $\mathrm{Pb}-\mathrm{Ac}$ $(\mathrm{p}<0.05)$ comparatively to the control group (Table 1$)$.

Table 1: Effect of oral administration of green or moringa leave extracts and their bio-yoghurts on the liver weight of albino rats fed $\mathrm{Pb}-\mathrm{Ac}$ in drinking water for five weeks.

\begin{tabular}{|c|c|c|}
\hline Treatment groups $^{\mathbf{1}}$ & $\begin{array}{c}\text { Absolute liver } \\
\text { weight }\end{array}$ & $\begin{array}{c}\text { Relative liver } \\
\text { weight }\end{array}$ \\
\hline GI (Control; SD) & $3.64 \pm 0.64^{\mathrm{e}}$ & $1.99 \pm 0.27^{\mathrm{e}}$ \\
\hline GII (Pb-Ac + SD) & $7.48 \pm 0.63^{\mathrm{a}}$ & $3.55 \pm 0.29^{\mathrm{a}}$ \\
\hline GIII (Pb-Ac + GTE + SD) & $4.10 \pm 0.64^{\mathrm{d}}$ & $2.5 \pm 0.38^{\mathrm{d}}$ \\
\hline GIV (Pb-Ac + MLE+ SD) & $3.78 \pm 0.49^{\mathrm{d}, \mathrm{e}}$ & $2.40 \pm 0.29^{\mathrm{d}}$ \\
\hline GV (Pb-Ac + Plain yoghurt & $6.24 \pm 0.64^{\mathrm{b}}$ & $3.11 \pm 0.11^{\mathrm{b}}$ \\
\hline + SD) & $5.48 \pm 0.40^{\mathrm{c}}$ & $3.07 \pm 0.22^{\mathrm{c}}$ \\
\hline GVI (Pb-Ac + Bio-yoghurt & & \\
\hline GTE+ SD) & $5.10 \pm 0.22^{\mathrm{c}}$ & $2.97 \pm 0.12^{\mathrm{c}}$ \\
\hline GVII (Pb-Ac + Bio-yoghurt & & \\
\hline MLE + SD) & & \\
\hline
\end{tabular}

${ }^{1}$ SD: Standard diet; GTE: green tea extract; MLE: moringa leaves extract All values were expressed as means \pm standard deviation. ${ }^{a-e}$ Different letters for each column indicate significant differences $(p<0.05)$

The relative liver weight of tested animal groups was ranked as $\mathrm{GII}<\mathrm{GV}<\mathrm{GVI}<\mathrm{GVII}<\mathrm{GIII}<\mathrm{GIV}<\mathrm{GI}$. These results showed that GTE and MLE gave the highest liver protective effects against the exposure to $\mathrm{Pb}-\mathrm{Ac}$. The fortification of yoghurt with plant extracts enhanced the therapeutic effects in compared to plain yoghurt which also showed relief potency $(p<0.05)$. In agreement with our results, Ibrahim et al [39] showed that $\mathrm{Pb}^{+2}$ at different concentration $\left(1 / 20,1 / 40\right.$ and $1 / 60$ of $\left.L_{50}\right)$ increased the weight of four organs (liver, kidney, spleen and heart). The increase in liver weight was associated with liver lipid accumulation [40] and total cholesterol and tri-glycerides were significantly increased in the rat liver extracts after 3 weeks of oral administration of lead acetate [41]. Growing interest in health effects of green tea and moringa are resulted in a number of published studies have demonstrated that their leave extracts (aqueous, hydroalcohol, or alcohol) possess a wide range of effective biological activities including antioxidant, tissue protective (liver, kidneys, heart, testes, and lungs), analgesic, antiulcer, antihypertensive, radio protective, and immune modulatory actions $[42,43]$.

\section{Effect on liver enzymes}

Plasma ALT and AST activities are monitored to indicate the liver functions in lead acetate intoxicated animals $(=500$ $\mathrm{mg} / \mathrm{kg}$ body wt) in relative to control rats (Fig 1 and 2). These results showed that oral uptake of Pb-Ac significantly stimulated 
$(\mathrm{P}<0.05)$ the ALT and AST activities which indicated the damage of liver cell. It is reported that lead toxic effects are caused liberation of ALT and AST. Increasing of liver enzymes secretion is followed by production of free radicals, enhancement of liver microsomal fluidity and transformation in the tissue structure $[44,45]$. Lead is a multifactorial toxic agent. It can directly disturb protein synthesis and enzymes activation, blocks trace elements absorption, and binds to sulfhydryl group resulting in decrease of body reserves of sulfhydryl antioxidants [46]. The inhibition of protein synthesis might be due to its damaging effect towards DNA and RNA structures [44].

In the present study, green tea or moringa leave extracts $(10 \%)$ and their bio-yoghurts (contained 1\% extract) were found to be very effective in terms of protection from lead acetate induced toxicity in the albino rats. The results in Fig 1 and 2 revealed that ALT and AST; liver enzymes were significant improvement $(\mathrm{P}<0.05)$ upon oral admiration of plant extracts and their bio-yoghurts. Oral uptake of green tea or moringa extracts and their fortified yoghurts were not only lowered ALT level compared to exposed $\mathrm{Pb}-\mathrm{Ac}$ group but also unexposed group (control group). Further, plain yoghurt also showed preventive effect as it is decreased the enzyme level (Fig 1).

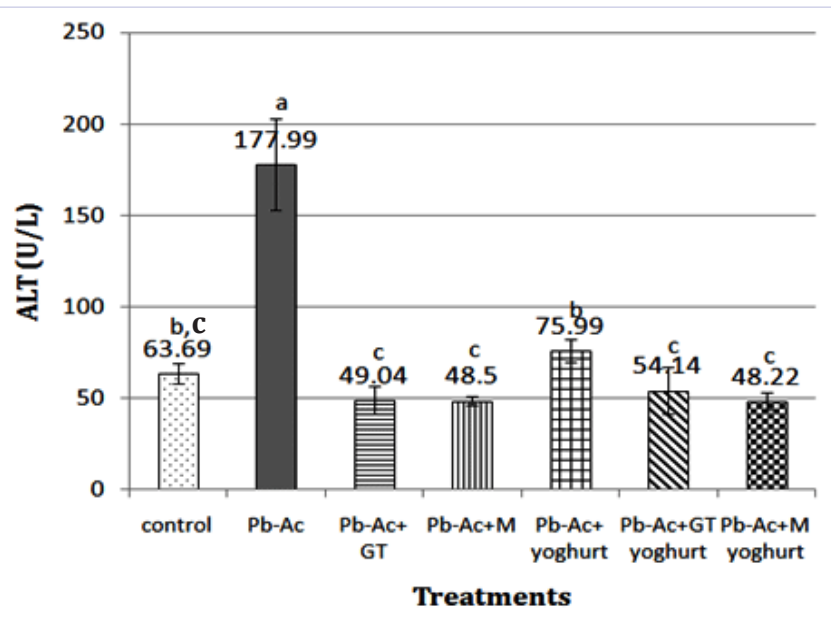

Figure 1: Levels of ALT in control and different treated rat groups ${ }^{1}$ ${ }^{1}$ Treatment groups, control: normal diet; $\mathrm{Pb}-\mathrm{Ac}$ : lead acetate+ normal diet; Pb-Ac+GT: lead acetate + green tea extract + normal diet; $\mathrm{Pb}+\mathrm{M}$ : lead acetate +moringa leave extract + normal diet; $\mathrm{Pb}-\mathrm{Ac}+$ yoghurt: lead acetate + plain yoghurt + normal diet; Pb-Ac + GT yoghurt: lead acetate +green tea yoghurt + normal diet; $\mathrm{Pb}-\mathrm{Ac}+\mathrm{M}$ yoghurt: lead acetate + moringa yoghurt + normal diet. Data are mean values of $n=6$ with standard deviation bars. ${ }^{a-c}$ Different letters indicate significant differences at $\mathrm{p}<0.05$.

In the case with AST both extracts and their bio-yoghurts were concurred the same protective effect while there were no significant different among the groups as the enzyme levels were similar to unexposed control group (Fig 2). In agreement with the present data, it is reported that the liver enzymes included ALT, AST and ALP were significantly increased in lead treated rats in comparison with non-treated group [47]. These enzymes were significantly reduced in lead exposed rats accompanied with oral fed GTE comparing with Pb-treated rats (Fig 2).

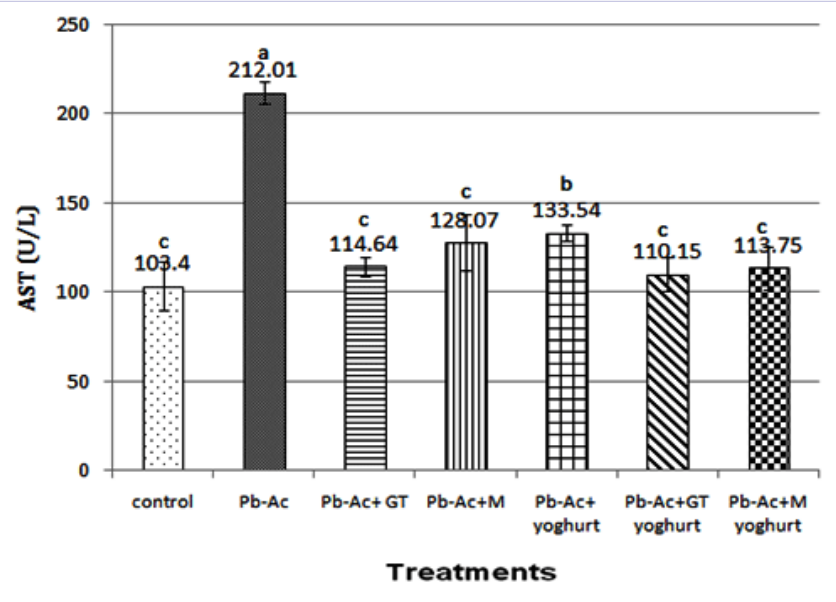

Figure 2: Levels of AST in control and different treated rat groups1 ${ }^{1}$ For treatment abbreviations see Fig 1 . Data are mean values of $n=6$ with standard deviation bars. ${ }^{a-c}$ Different letters indicate significant differences at $\mathrm{p}<0.05$.

Antioxidant components play an indispensable role to afford safeguard against oxidative stress maintain a balance between the active oxygen species formation and the endogenous antioxidant level.

Dietary polyphenols have a potent antioxidants play a key role in the synthesis of intracellular glutathione, Glutathione Peroxidase (Gpx) and attenuate mitochondrial oxidative stress [48]. Green tea, Camellia sinensis is among the most common sources of polyphenol-rich foods and beverages. Researches on antioxidant content of green tea had captured remarkable attention as it able to mitigate metabolic syndrome features and to cut down the risks for cardiovascular diseases $[49,50]$. Different phenolic compounds were identified in the present study using GC-MS analysis included phenolic acids such as caffeic acid, and flavonols such as myricetin (data not shown). In study on adults suffered from the metabolic syndrome, feeding with green tea resulted in increasing of glutathione and plasma antioxidant capacity [51].

Recently, the effect of GTE supplementation on liver enzymes in patients with nonalcoholic fatty has studied in double-blind, placebo-controlled, randomized clinical trial [52]. Green tea treated group showed significant reductions in ALT and AST levels after 12 weeks of administration $(\mathrm{P}<0.001)$.

Moringa oleifera Leaves (MOL) are considered as oasis of micro nutrients include essential amino acids, vitamins, minerals and $\beta$-carotene [53]. For these reasons many countries are using it as an alternative source for nutritional supplements and growth promoters [54].

Curative effects of different plant parts (flower, leaves, seed, pods and stem) in rats intoxicated by acetaminophen are studied [55]. The enzyme liver markers i.e. ALT and AST and the levels of oxidative damage markers including malondialdehyde 
(MDA), and 4-hydroxynonenal (4-HNE) protein showed a significant increase after administration of moringa flowers and leaves hydroethanolic extracts. Moreover, the levels of reduced glutathione (GSH), superoxide dismutase (SOD) and catalase (CAT) were significantly increased $(\mathrm{p}<0.05)$ compared to the severity damage liver in intoxicated rat group [55].

The moringa leaves contain diverse classes of phytochemicals beside of vitamins and carotenoids. These compounds are mainly contributed to the antioxidant properties as well as other biological activities [56]. Inside the body, the generation of vitamin A from $\beta$-carotene content of MOL is efficiently carried out and gave significant hepatoprotective effects. Several studies have strongly suggested the therapeutic effects of MOL phenolic compounds refer to its antioxidant properties. The main target of antioxidant activity has been related with the ability of phenolic compounds to scavenge the generation of free radicals [57]. Specific phenolic compounds also may play a role in the production of other antioxidant enzymes i.e. glutathione-S-transferase. In some cases, a certain phenolic classes have the ability to bind minerals which might be beneficial. For instance copper and iron can be initiators in the production of hydroxyl radical by the Fenton and Haber-Weiss reactions [58]. The GC-MS analysis revealed the presence of various phenolic compounds in MOLE (data not shown).

Plain yoghurt exhibited a protective effect against lead intoxication led to improve ALT and AST levels (Figs 1 and 2). Milk is recognized as a main source of high quality proteins and also bioactive peptides. A lot of scientific evidence is suggested that milk proteins have potential anticarcinogenic, antihypertensive, immune modulatory effects. Whey proteins showed to play a crucial role against cancer (colon, breast, and prostate gland). The anti-carcinogenic effects might be probably due to its ability to enhance cellular levels of glutathione, as well as promoting hormonal and cell-mediated immune responses [59]. In agreement with the presented results, Abdel-Salam et al., [60] found that whey proteins alone or in combination with Artemisia and Capparis extracts had enhanced enzyme liver functions by lowering ALT and AST levels in led exposed rats. McIntosh et al [61] has been indicated that whey protein fractions (lactalbumins, lactoglobulin, lactoferrin, lactoperoxidase and immunoglobulins) own anti-carcinogenic activity. Milk protein active peptides can be raise from inactive forms within the sequence of parent protein during gastrointestinal digestion or food enzymatic and fermentation processing. According to Kamau et al. [62], many bioactive peptides can be released through enzymatic hydrolysis of whole milk or precursor protein.

In the present study plain yogurt had a phenolic content (data not shown) which reflected that the milk proteins are the main source of these compounds. Yogurt itself contains amino acid such as tyrosin that has side chain group the same as phenolic group which give rise to the reading in total phenol [63]. It is suggested that during fermentation phenolic acids such as ferulic and p-coumaric acid could be utilized by microorganisms converted to other phenolic acids such as vanillic acid and p-hydroxybenzoic acid before the break down of aromatic ring
$[6,65]$.

\section{Effect on lipid profile}

In regard to the results of serum lipid profile of lead intoxicated rat group, it is indicated that among the different types of serum lipoproteins - total cholesterol (TC) and the low density lipoprotein (LDL) were increased in opposite the high density lipoprotein (HDL) was significantly lowered meanwhile, triglyceride level (TG) kept unchanged (Fig 3-6).

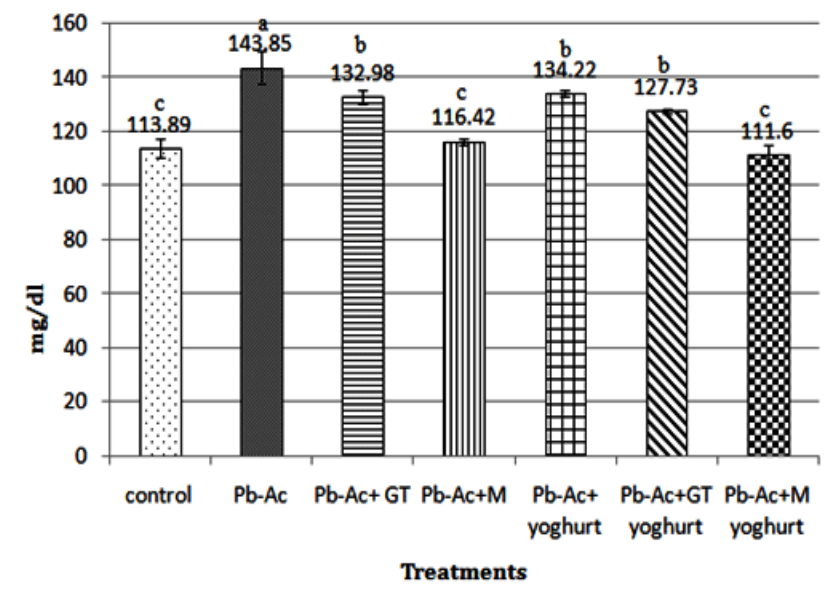

Figure 3: Levels of total cholesterol (TC) in control and different treated rat groups ${ }^{1}$

${ }^{1}$ For treatment abbreviations see Fig 1 . Data are mean values of $n=6$ with standard deviation bars. ${ }^{\text {a-c }}$ Different letters indicate significant differences at $\mathrm{p}<0.05$.

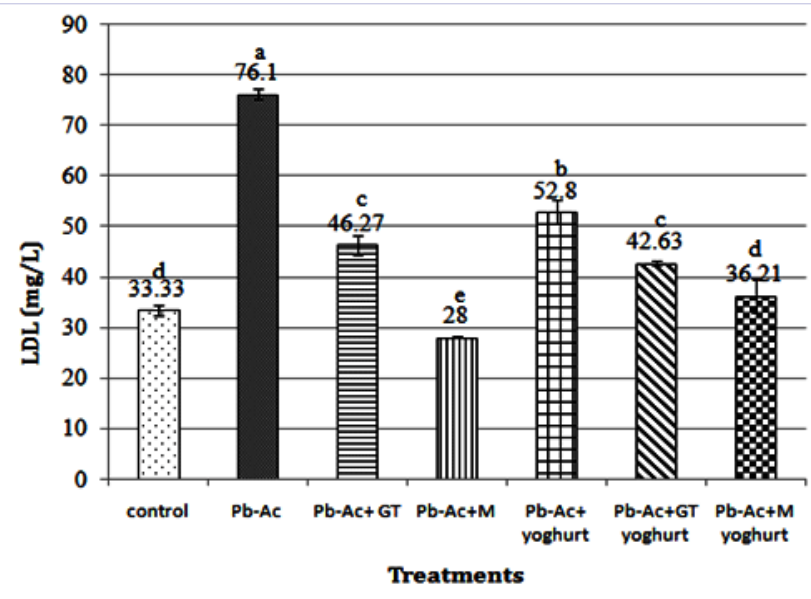

Figure 4: Levels of low density lipoprotein (LDL) in control and different treated rat groups ${ }^{1}$

${ }^{1}$ For treatment abbreviations see Fig 1 . Data are mean values of $n=6$ with standard deviation bars. ${ }^{\text {a-e }}$ Different letters indicate significant differences at $\mathrm{p}<0.05$. 


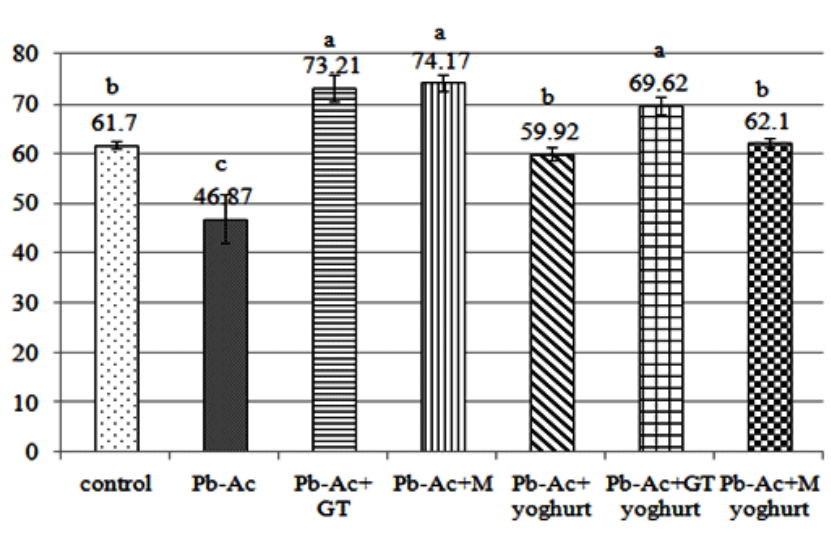

Treatments

Figure 5: Levels of high density lipoprotein (HDL) in control and different treated rat groups ${ }^{1}$

${ }^{1}$ For treatment abbreviations see Fig 1. Data are mean values of $n=6$ with standard deviation bars. ${ }^{\mathrm{a}-\mathrm{c}}$ Different letters indicate significant differences at $\mathrm{p}<0.05$.

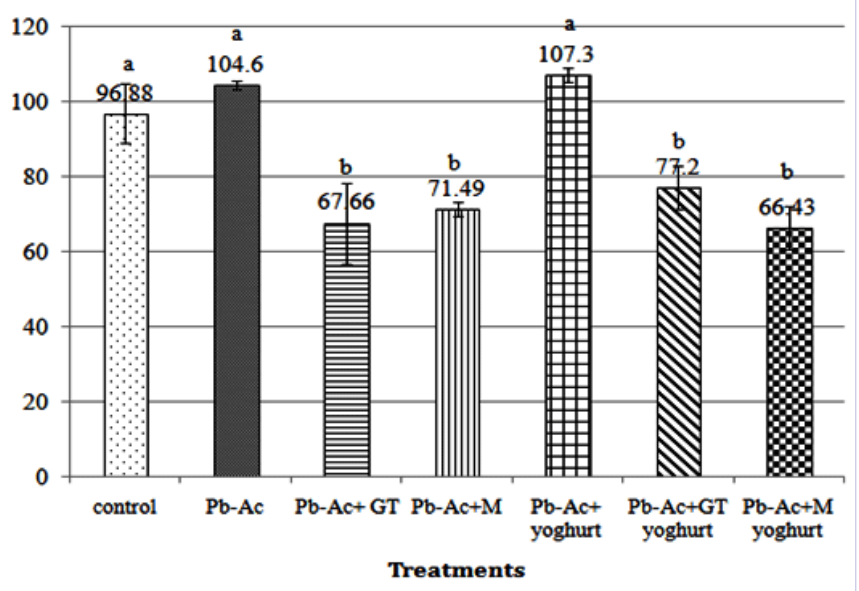

Figure 6: Level of triglyceride in control and different treated rat groups $^{1}$

${ }^{1}$ For treatment abbreviations see Fig 1 . Data are mean values of $n=6$ with standard deviation bars. ${ }^{a-b}$ Different letters indicate significant differences at $\mathrm{p}<0.05$.

\section{Effect on plasma total cholesterol}

As shown in Fig (3) oral fed of intoxicated Pb-Ac with green tea or moringa leaves extracts $(10 \%)$ and its formulated bio-yoghurt was efficient in reducing the total cholesterol level from $143.85 \mathrm{mg} / \mathrm{dl}$ in the $\mathrm{Pb}-\mathrm{Ac}$ oral intoxicated group to become $132.98 \mathrm{mg} / \mathrm{dl}$ and $116.42 \mathrm{mg} / \mathrm{dl}$ in rats that fed on green tea and moringa extracts respectively. Yoghurt showed curing effect by lowering total cholesterol in compare with lead acetate fed group $(\mathrm{P}<0.05)$. Feeding with moringa yoghurt led to decrease cholesterol to level untreated lead acetate group (control). Oral administration of moringa was more effective to lower cholesterol compared to green tea.

\section{Effect on plasma LDL -cholesterol}

In Fig (4) rats fed on Pb-Ac supplemented with the green tea or moringa extracts exhibited a significant decrease $(\mathrm{P}<0.05)$ on the levels of LDL-cholesterol than rats fed Pb-Ac without the addition of the tested extracts. The addition of moringa extract showed to have a higher effect than green tea extract $(\mathrm{P}<0.05)$. Fed plain yoghurt in the presence of Pb-Ac decreased the LDL than rats fed on $\mathrm{Pb}-\mathrm{Ac}$ alone. Oral fed with bio-yogurts produced with plant extracts affected LDL. The LDL level of moringa yoghurt rat group was similar to control rat group (Fig 4).

\section{Effect on plasma HDL- cholesterol}

In the rat groups that fed on the $\mathrm{Pb}-\mathrm{Ac}$ with green tea or moringa extract or its bio-yoghurt, the plasma HDL Cholesterol levels were significantly higher than the rats fed on $\mathrm{Pb}$-Ac alone $(\mathrm{P}<0.05)$. The highest levels of HDL cholesterol were noticed with extracts received groups while there was no significant effect between green tea and moringa rat groups (Fig 5). Yoghurt enhanced HDL Cholesterol level compared to $\mathrm{Pb}$-Ac fed group $(\mathrm{P}<$ 0.05 ) while fortification of yoghurt with either extract increased HDL-Cholesterol to level control group.

\section{Effect on plasma triglycerides}

Changes in the plasma triglycerides levels of rats fed on different tested diets are given in Fig (6). Level of triglyceride in the rats groups included control, oral fed $\mathrm{Pb}-\mathrm{Ac}$ and $\mathrm{Pb}-\mathrm{Ac}+$ yoghurt showed no significant differences $(\mathrm{P}<0.05)$. Green tea or moringa extracts alone or in fortified bio-yoghurts reported significant decrease $(\mathrm{P}<0.05)$ in the plasma triglycerides levels compared not only to $\mathrm{Pb}-\mathrm{Ac}$ group but also with control group.

The increment of LDL values in rabbits exposed to $\mathrm{Pb}$ Ac showed to increase in the LDL-cholesterol biosynthesis by hepatic cells as well to decrease in the molecules reuptake by a receptor mediated endocytosis [66]. It is reported that lead exposure also resulted in enhanced hepatic cholesterogenesis and hypertriglyceridemia [40]. Hami et al., [67] found a positive correlation between the serum lead level and the levels of serum total cholesterol and LDL cholesterol. The Pb-Ac exposure elevated oxidative stress resulted in defect in the receptor parallel with a decrease in the reuptake of the cholesterol molecules remain a high serum level of it [68-71]. The presence of HDL molecules indicates that the cholesterol is transported from the peripheral tissues to liver to be metabolized and excreted as bile acids [72]. The low intracellular cholesterol level is triggered hepatocyts to reduce the HDL biosynthesis [66]. In the present study the reduction of HDL in lead group might be attributed to a defect in the intrahepatic cholesterol metabolisms a result to persisting of serum LDL and VLDL caused by lead oxidative damage. In corresponding with the present study, it is reported that oral uptake of $2.5 \mathrm{mg} / \mathrm{kg}$ bwt Pb-Ac caused an increment in total cholesterol, LDL cholesterol, total triacylglycerol and reduction in HDL cholesterol [73].

A number of epidemiological studies have been suggested that the consumption of green tea is well correlated with a lower risk factors would cause coronary heart disease; 
however the mechanisms of action for these findings have remained unclear. Many studies have shown that green tea may impact the cardiovascular function through mechanisms of action related to LDL-cholesterol oxidation [74, 75]. Antioxidant activity of green tea EC ((-)-epicatechin) and EGCG ((-)-epigallocatechin3 -gallate) have able to reduce a risk for atherosclerosis and heart disease by suppressing the oxidation of LDL cholesterol. In vitro study demonstrated that the antioxidant activity of EGCG on LDL oxidation was stronger than that of EC [76]. Trevisanato and Kim [77] indicated that green tea polyphenols may reduce atherogenesis by slowing the oxidative rate of LDL-cholesterol and relative episodes i.e. foam cell formation, endothelial cytotoxicity and induction of proinflammatory cytokines. It is suggested that consumption of ground green tea inhibited the susceptibilities of LDL cholesterol and plasma to oxidation by $\mathrm{CuSO} 4$ [78]. Bioavailability studies indicate that green tea polyphenols can accumulate in the body at concentrations comparable to those applied in vitro by man researchers [79]. Other report demonstrated that catechins have able to reduce cholesterol levels and cholesterol absorption. In dose-response experiment, the action of fed 1\% EGCG in hypercholesterolemic rats showed a significant reduce of total cholesterol and LDL cholesterol plasma levels when compared to the non-fed group after 4 weeks [80]. The authors suggested that the EGCG green tea affects lipid metabolism by interfering with the cholesterol micellar solubilization in the digestive tract, and in turn decreases the absorption of cholesterol.

More recently the protective role of green tea catechins against obesity and associated disorders i.e hypercholesterolemia and hyperglycemia was studied in rats [81]. The total cholesterol and LDL-cholesterol were considerably reduced by $14.42 \%$ in high cholesterol + high sucrose diet and $30.43 \%$ in high cholesterol diet, respectively. In contradiction to lipid profile, drinking trial with (-)-epigallocatechin-3-gallate (EGCG) reduced the trait compared to catechins based functional drink. In human trail, 15 human volunteers had subjected to the daily consumption of $1200 \mathrm{ml}$ of green tea for 30 days. The results showed that the uptake of green tea promoted the decrease of total cholesterol and LDL-cholesterol levels after 15 days [82].

The effect of co-production of medicinal herbs with dairy products has attracted researchers to give a clue about the interaction effects on the functions of different active compounds and whether it would oppose their health roles. It is recently reported that the addition of green tea extract to dairy matrix (milk, yoghurt and light cheddar cheese) showed a significant improve in polyphenol release and higher antioxidant capacity in order of milk $\geq$ yoghurt $>$ cheese. of the digest $(\mathrm{P}<0.01$ ), with milk and stability in the intestinal phase and increased the antioxidant activity by $29 \%$ (cheese) to $42 \%$ (milk) compared to the control. These results support our findings of protective effects of green tea yoghurt against hyperlipidemia effect of lead acetate. These data suggest that continuous consumption of fortified green tea dairy products helps to maintain the integrity and antioxidant activity of polyphenols during digestion [83].

The widespread combination of diuretic along with lipid and blood pressure lowering constituents make Moringa oleifera highly useful in corner heart disorders. The consumption of the crude moringa leaves extract $(1 \mathrm{mg} / \mathrm{g}$ extract) with coadministrated with high-fat diet reduced cholesterol level by in serum (14.35\%), liver (6.40\%), and kidney (11.09\%), compared to the high-fat fed group [84]. It is suggested that a significant cholesterol reducing effect of moringa leaves extract might be attributed to the presence of a bioactive phytoconstituent, i.e. $\beta$-sitosterol [84]. Saluja et al. [85] reported that both b-sitosterol isolated from the stem of a variety of Moringa oleifera Lam and b-sitosterol found a plant sterol had structure similar to that of cholesterol, except for the substitution of an ethyl group at C24 of its side chain.

Other plant parts of moringa have a potential hypocholesterolemia effect. Moringa fruit has been able to reduce the serum cholesterol, LDL-cholesterol, triglycerides, phospholipids, and atherogenic index lipid in addition to lower the lipid profile of liver, heart and aorta with a high fecal cholesterol excretion in rabbits fed with high cholesterol diet [86]. Rat received fatty diet with moringa leaves extract ranged from $100-300 \mathrm{mg} / \mathrm{kg} /$ day, the cholesterol values decreased significantly in range from $4-8 \%$ when compared with rats in normal and untreated groups, $\mathrm{p} \leq 0.05$ [87]. The presented data are in agreement with the earlier report by Raida et al. [88]. They found that the moringa leaf extract reduced serum cholesterol, triglycerides, VLDL and LDL in rabbit fed with high fat diet. Similar results were reported [89] in hypercholesteremic albino wistar rats where methanolic morniga leaves extract were found to reduce all the lipid parameters (cholesterol, VLDL, LDL TG and atherogenic index) while the HDL increased as compared to the corresponding high-fat group (control). Moreover, in hyperlipidemia rats oral administration of moringa leaves extracts $(100-200 \mathrm{mg} / \mathrm{kg}$ bwt) showed significant reduction levels $(\mathrm{p}<0.001)$ of body weight, total cholesterol, triglycerides, low density lipoprotein and similar increase in high density lipoprotein level. Atherogenic index was significantly reduced in the moringa treated groups at tested dose levels [90]. In diabetes II and obese subjects ( 9 men and 6 women), it was observed that administration of moringa power with food the percentage decrease in serum LDL levels was $30.94 \%$ (45.66- 31.53 mg per $100 \mathrm{ml}$ of serum) [91].

It is conclude that the daily intake of green tea or moringa leave extracts succeeded to protect animals against lead intoxication. Moreover, addition of plant extracts with fermented yoghurt has improved significantly the anti-oxidative effects of the produced bio-yoghurts in compared to plain yoghurt. There are a very good possibility that medicinal herb yogurt would be a very effective part of daily diet to give a sustainable protection against oxidative stress.

\section{References}

1. Wu R, Wang W, Yu D, Zhang W, Li Y, Sun Z, et al. Proteomics analysis of Lactobacillus casei Zhang, a new probiotic bacterium isolated from traditional home-made Koumiss in Inner Mongolia of China. Mol Cell Protecteomics. 2009;8(10):2321-2338. doi: 10.1074/mcp.M800483- 
MCP200.

2. Kullisaar T, Songisepp E, Mikelsaar M, Zilmer K, Vihalemm T, Zilmer M. Antioxidative probiotic fermented goats' milk decreases oxidative stress-mediated atherogenity in human subjects. Brit J Nutr. 2003;90(2):449-456.

3. Korczynska M, Weinbreck F, Ouwehand AC. The gut microbiota and weight management Any role for probiotics? Agro Food Industry hitech. 2008;19(5):436-442.

4. Hu D, Huang J, Wang Y, Zhang D, Qu Y. Dairy foods and risk of stroke: a meta-analysis of prospective cohort studies. Nutr Metab Cardiovasc Dis. 2014;24(5):460-469.

5. Soedamah-Muthu SS, Ding EL, Al-Delaimy WK, Hu FB, Engberink MF, Willett WC, et al. Milk and dairy consumption and incidence of cardiovascular diseases and all-cause mortality: dose-response metaanalysis of prospective cohort studies. Am J Clin Nutr. 2011;93(1):158171. doi: $10.3945 /$ ajcn.2010.29866

6. Tong X, Dong JY, Wu ZW, Li W, Qin LQ. Dairy consumption and risk of type 2 diabetes mellitus: a meta-analysis of cohort studies. Eur J Clin Nutr. 2011;65(9):1027-1031. doi: 10.1038/ejcn.2011.62

7. Aune D, Norat T, Romundstad P, Vatten LJ. Dairy products and the risk of type 2 diabetes: a systematic review and dose-response metaanalysis of cohort studies. Am J Clin Nutr. 2013;98(4):1066-1083. doi 10.3945/ajcn.113.059030

8. Chiu S. Is green tea good for you? J Food Sci Educ. 2006;5(4):70-71.

9. Silva LA, Silveira PC, Pinho CA, Tuon T, Pizzol FD, Pihno R. $\mathrm{N}$-acetylcysteine supplementation and oxidative damage and inflammatory response after eccentric exercise. Int J Sport Nut Exer Metabolism. 2008;18(4):379-388.

10. Ferruzzi MG, Green RJ. Analysis of catechins from milk-tea beverages by enzyme assisted extraction followed by high performance liquid chromatography. Food Chem. 2006;99(3):484-491.

11. Amirdivani $\mathrm{S}, \mathrm{Hj}$ Baba AS. Green tea yogurt: major phenolic compounds and microbial growth. J Food Sci Technol 2015;52(7):4652-4660. doi 10.1007/s13197-014-1670-6.

12. Giroux HJ, De Grandpré G, Fustier P, Champagne CP, St-Gelais D, Lacroix $\mathrm{M}$, et al. Production and characterization of Cheddar-type cheese enriched with green tea extract. Dairy Sci and Technol. 2013;93(3):241-254

13. Iqbal S, Bhanger MI. Effect of season and production location on antioxidant activity of Moringa oleifera leaves grown in Pakistan. J. Food Comp and Anal. 2006;19(6-7):544-551.

14. Arabshahi-DS, Devi DV, Urooj A. Evaluation of antioxidant activity of some plant extracts and their heat, $\mathrm{pH}$ and storage stability. Food Chem. 2007;100(3):1100-1105.

15. Fahey JW. M. oleifera: A review of the medical evidence for its nutritional, therapeutic, and rophylactic properties. Part 1 . Trees for Life Journal. 2005;1:5.
16. Bennett, RN, Mellon FA, Foidl N, Pratt JH, Dupoint SM, Perkins L, et al. Profiling Glucosinolates and phenolics in vegetative and reproductive tissues of the multi-purpose trees M. oleifera L. (Horseradish Tree) and Moringa stenopetala L. J Agri Food Chem. 2003;51(12): 35463553.

17. Siddhuraju P, Becker K. Antioxidant properities of various solvent extracts of total phenolic constituents from three different agroclimatic origins of drumstick tree (M. oleifera Lam.) Leaves. J Agric Food Chem. 2003;51(8):2144-2155.

18. Gupta K, Barat GK, Wagle DS, Chawla HKL. Nutrient contents and antinutritional factors in conventional and non-conventional leafy vegetables. Food Chem. 1989;31(2):105-116

19. Soliva CR, Kreuzer M, Foidl N, Foidl G, Machmüller A, Hess HD. Feeding value of whole and extracted Moringa oleifera leaves for ruminants their effects on ruminal fermentation in vitro. Anim Feed Sci Technol. 2005;118(1-2): 47-62.

20. Sarwatt, SV, Kapange SS, Kakengi AMV. Substituting sunflower seedcake with Moringa oleifera leaves as a supplemental goat feed in Tanzania. Agroforestry Systems. 2002;56(3):241-247.

21. Smolin LA, Grosvenor MB. Nutrition: Science \& Application. 2007.

22. Hekmat S, Morgan K, Soltani M, Gough R. Sensory evaluation of locallygrown fruit purees and inulin fibre on probiotic yogurt in mwanza, Tanzania and the microbial analysis of probiotic yogurt fortified with Moringa oleifera. J Health Popul Nutr. 2015;(1)33:60-67.

23. Mahami T, Ocloo FCK, Odonkor ST, Owulah C, Coffie SA. Preliminary study on the influence of moringa seed extracts supplementation on the yield and quality of cottage cheese. Int J Recent Trends in Sci. Technol. 2012;2(1) 4-8.

24. Oduro I, Ellis WO, Owusu D. Nutritional potential of two leafy vegetables: Moringa oleifera and Ipomoea batatas leaves. Sci Res Essay. 2008;3(2):57-60.

25. Dachana KB, Rajiv J, Indrani D, Prakash J. Effect of dried moringa (moringa oleifera lam) leaves on rheological, microstructural, nutritional, textural and organoleptic characteristics of cookies. J Food Qual. 2010;33(5):660-677. DOI: 10.1111/j.1745-4557.2010.00346.x

26. Chumark P, Khunawat P, Sanvarinda Y, Phornchirasilp S, Morales $\mathrm{PN}$, Phivthong-ngam $\mathrm{L}$, et al. The in vitro and ex vivo antioxidant properties, hypolipidaemic and antiatherosclerotic activities of the water extract of Moringa oleifera Lam. leaves. Jof Ethnopharmacology. 2008;116(3):439-446. doi: 10.1016/j.jep.2007.12.010

27. DanMalam HU, Abubakar Z, Katsayal UA. Pharmacognostic studies on the leaves of Moringa oleifera. Nig J Natur Prod Med. 2001;5:45-49. DOI: 10.4314/njnpm.v5i1.11723

28. Dahiru D, Obnubiyi JA, Umaru HA. Phytochemical screening and antiulcerogenic effect of Moringa. African Journal of Traditional, Complimentary and Alternatives Medicines. 2006;3(3):70-75.

29. Wahab AA, Mabrouk MA, Joro JM, Oluwatobi SE, Bauchi ZM, John AA. Ethanolic extract oF Phoenix dactylifera L. prevents lead induced 
hematotoxicity in rats. Cont J. Biomed Sci. 2010;4:10 - 15.

30. Sharma R, Panwar K, Mogra S. Alterations in developing RBCs after prenatal and postnatal exposure to lead acetate and Vitamins. Int ] Pharm Sci Res. 2013;4(8):3214-3224.

31. Berkovich L, Earon G, Ron I, Rimmon A, Vexler A, Lev-Ari S. Moringa oleifera aqueous leaf extract down-regulates nuclear factor-kappaB and increases cytotoxic effect of chemotherapy in pancreatic cancer cells. BMC Complement Altern Med. 2013;8(19):212. doi: 10.1186/1472-6882-13-212.

32. Gella FJ, Olivella T, Cruz Pastor M, Arenas J, Moreno R, Durban R, et al. A simple procedure for routine determination of aspartate aminotransferase and alanine aminotransferase with pyridoxal phosphate. Clin Chim Acta. 1985;153(3): 241-247.

33. Bucolo G, David H. Quantitative determination of serum triglycerides by the use of enzymes. Clin Chem. 1973;19(5):476-482.

34. Fossati P, Prencipe L. Serum triglycerides determined colorimetrically with an enzyme that produces hydrogen peroxide. Clin Chem. 1982;28(10):2077-2080.

35. Meiattini F, Prencipe L, Bardelli F, Giannini G, Tarli P. The 4-hydroxybenzoate/4-aminophenazone chromogenic system used in the enzymic determination of serum cholesterol. Clin Chem. 1978;24(12):2161-2165.

36. Grove TH. Effect of reagent $\mathrm{pH}$ on determination of highdensity lipoprotein cholesterol by precipitation with sodium phosphotungstate-magnesium. Clin Chem. 1979;25(4):560-564.

37. Friedewald WT, Levy RI, Fredrickson DS. Estimation of the concentration of low-density lipoprotein cholesterol in plasma, without use of the preparative ultracentrifuge. Clin Chem. 1972;18(6):499502.

38. Waller RA, Duncan DB. A Bayes rule for the symmetric multiple comparison problems. J. Am. Stat. Assoc. 1969;64(328):1484-1503.

39. Ibrahim NM, Eweis EA, El-Beltagi HS, Abdel-Mobdy YE. Effect of lead acetate toxicity on experimental male albino rat. Asian Pac J Trop Biomed. 2012;2(1):41-46. doi: 10.1016/S2221-1691(11)60187-1

40. Ademuyiwa OR, Agarwal R, Chandra R, Beharia JR. Lead-induced phospholipidosis and cholerterogensis in rat tissues. Chem Biol Interact. 2009;179(2-3):314-320. doi: 10.1016/j.cbi.2008.10.057.

41. Newairy AA, Abdou HM. Protective role of flax lignans against lead acetate induced oxidative damge and hyperlipidemia in rats. Food Chem Toxicol. 2009;47(4):813-818. doi: 10.1016/j.fct.2009.01.012

42. Stohs SJ, Hartman MJ. Review of the Safety and Efficacy of Moringa oleifera. Phytother. Res. 2015;29(6):796-804. doi: 10.1002/ptr.5325.

43. Chacko SM, Thambi PT, Kuttan R, Nishigaki I. Beneficial effects of green tea: A literature review. Chinese Med. 2010;13(5):2-9. doi: 10.1186/1749-8546-5-13

44.Shalan MG, Mostafa MS, Hassouna MM, El-Nabi SE, El-Refaie A. Amelioration of lead toxicity on rat liver with vitamin $\mathrm{C}$ and silymarin supplements. Toxicol. 2005;206(1): 1-15.

45. Abdallah GM, El-Sayed M, Osama M, Abo-Salem OM. Effect of lead toxicity on coenzyme $\mathrm{Q}$ levels in rat tissues. Food Chemical Toxicol. 2010;48(6):1753-1756

46. Sharma V, Kansal LA, Sharma A. Prophylactic efficacy of Coriandrum sativum (Coriander) on testes of lead-induced mice. Biolog Trace Elements Res 2009;136(3): 337-354. doi: 10.1007/s12011-0098553-0

47. Ait HN, Mehdid A, Guellil H, Slimani M, Aoues Aek. Positive effects of green tea (Camellia Sinensis) on hepatic dysfunction induced by lead acetate in male rat. Int J Drug Dev Res. 2014;6(2): 87-96.

48. Moskaug Jø, Carlsen H, Myhrstad MC, Blomhoff R. Polyphenols and glutathione synthesis regulation. Am J Clin Nutr. 2005;81(1S):277S283S.

49. Thielecke F, Boschmann M. The potential role of green tea catechins in the prevention of the metabolic syndrome-a review. Phytochem. 2009;70(1):11-24. doi: 10.1016/j.phytochem.2008.11.011.

50. Phung OJ, Baker WL, Matthews LJ, Lanosa M, Thorne A, Coleman CI. Effect of green tea catechins with or without caffeine on anthropometric measures: a systematic review and meta-analysis. Am J Clin Nutr. 2010;91(1):73-81. doi: 10.3945/ajcn.2009.28157.

51.Basu A, Betts NM, Mulugeta A, Tong C, Newman E, Lyons TJ. Green tea supplementation increases glutathione and plasma antioxidant capacity in adults with the metabolic syndrome. Nutr res. 2013;33(3):180-187. doi: 10.1016/j.nutres.2012.12.010

52. Pezeshki A, Safi S, Feizi A, Askari G, Karami F. The effect of green tea extract supplementation on liver enzymes in patients with nonalcoholic fatty liver disease. Int J Prev Med. 2016;7(1):28-33. doi: 10.4103/2008-7802.173051

53. Sharma N, Gupta PC, Rao ChV. Nutrient content, mineral, content and antioxidant activity of Amaranthus viridis and Moringa oleifera leaves. Res J Med Plant. 2012;6(3):253-259.

54. Anwer F, Latif S, Ashraf M, Gilani AH. Moringa oleifera: A food plant with multiple medicinal uses. Phytother Res. 2007;21(1):17-25.

55. Fakurazi S, Sharifudin SA, Arulselvan P. Moringa oleifera hydroethanolic extracts effectively alleviate acetaminophen-induced hepatotoxicity in experimental rats through their antioxidant nature. Molecules 2012;17(7): 8334-50. doi: 10.3390/molecules17078334.

56. Dillard CJ, German JB. Phytochemicals: nutraceuticals and human health. J Sci Food Agric. 2000;80:1744-1756

57. Verma AR, Vijayakumar M, Mathela CS, Rao, CV. In vitro and in vivo antioxidant properties of different fractions of Moringa oleifera leaves. Food Chem. Toxicol. 2009;47(9):2196-2201. doi: 10.1016/j. fct.2009.06.005

58. Ferguson LR. Role of plant polyphenols in genomic stability. Mutat Res. 2001;475(1-2):89-111.

59. Davoodi H, Esmaeili S, Mortazavian AM. Effects of milk and milk 
products consumption on cancer: A review. Compr Rev Food Sci Food Safety. 2013;12(3):249-264.

60. Abdel-Salam AM, El-Ziney MG, Zaghloul AH, Babiker AY, Mousa HM. The effectiveness of whey proteins mixed with hot-water extract of Artemisia and Capparis spp. against lead acetate-contamination in rats. J Food Agric Environ. 2009;7(3\&4):139-144.

61. McIntosh GH, Royle PJ, Le Leu RK, Regester GO, Johnson MA, Grinsted RL, et al. Whey Proteins as Functional Food Ingredients? Int Dairy J. 1998;8(5-6):425-434.

62. Kamau SM, Lu R R, Chen W, Liu XM, Tian FW, Shen Y, et al. Functional significance of bioactive peptides derived from milk proteins. Food Rev Inter. 2010;26(4):386-401.

63. Shah, H. Effects of milk-derived bioactives: an overview. British J Nutr. 2000;84(S1):3-10.

64. Turner JA, Rice EL. Microbial decomposition of ferulic acid in soil. J Chem Ecol. 1979;1(1):41-58.

65. Blum U. Effects of microbial utilization of phenolic acids and their phenolic acid breakdown products on allelpathic interactions. J Chem Ecol. 1998;24(4):685-708.

66. Tietz NW. Text book of clinical chemistry. 3rd Ed. CA. Burtis, ER. Ashwood, EB. Saunders. 1698-1704. 1999.

67. Hami J, Dashti GR, Nemat-bakhsh M, Afshar M, Ghaffari HR. The relationship between high dose lead exposure and serum lipids and lipoprotein levels. Shiraz E-Medical J. 2006;7(2):1-7.

68. Ponce-Canchihuamán JC, Pérez-Méndez O, Hernández-Muñoz R, Torres-Durán PV, Juárez-Oropeza MA. Protective effects of Spirulina maxima on hyperlipidemia and oxidative-stress induced by lead acetate in the liver and kidney. Lipids Health Dis. 2010;35(9):1-7. doi: 10.1186/1476-511X-9-35

69. Nagaraja H, Tan J, Srkumer C, Anupama B. Protective effects of Alphapolic acid against lead acetate - inducwd oxidative stress in the bone marrow of rats. Int J Pharmacol. 2011;7(2):217-227.

70. Samir AEB. Beneficial effect of combined administration of vitamin $\mathrm{C}$ and vitamin $\mathrm{E}$ in amelioration of chronic lead hepatotoxicity. The Egyptian J Hospital Med. 2002;23(3):371-384.

71. Patrick L. Lead toxicity part II: the role of free radical damage and the use of 432 antioxidants in the pathology and treatment of lead toxicity. Altern Med Rev. 2006;11(2):114-127.

72. Kwiterovich PO. The metabolic pathways of high-density lipoprotein, low-density lipoprotein, and triglycerides: a current review. Am J Cardiol. 2000;86(12):5L-10L.

73. Alqayim MA. Antiatherogenic effects of Vitamin E against lead acetate induced hyperlipidemia. Mesop Environ J. 2015;1(2):85-95.

74. McKay DL, Blumberg JB. The role of tea in human health: An update. J Am Coll Nutr 2002;21(1):1-13.

75. Ishikawa T, Suzukawa M, Ito T, Yoshida H, Ayaori M, Nishiwaki M, et al. Effect of tea flavonoid supplementation on the susceptibility of low-density lipoprotein to oxidative modification. Am J Clin Nutr. 1997;66(2):261-266.

76. Gomikawa S, Ishikawa Y. Effects of catechins and ground green tea drinking on the susceptibility of plasma and LDL to the oxidation in vitro and ex vivo. J Clin Biochem Nutr. 2002;32(1):55-68.

77. Trevisanato S, Kim Y. Tea and health. Nutr Rev. 2000;58(1):1-10.

78. Gomikawa S, Ishikawa Y, Hayase W, Haratake Y, Hirano N, Matuura Het al. Effect of ground green tea drinking for 2 weeks on the susceptibility of plasma and LDL to the oxidation ex vivo in healthy volunteers. Kobe J Med Sci. 2008;54(1):E62-72.

79. Scalabert A, Williamson G. Dietary intake and bioavailability of polyphenols. J Nutr. 2000;130(S8):2073S-2085S.

80. Raederstoff DG, Schlachter MF, Elste V, Weber P. Effect of EGCG on lipid absorption and plasma lipid levels in rats. J Nutr Biochem. 2003;14(6):326-332.

81. Ahmad RS, Butt MS, Sultan MT, Mushtaq Z, Ahmad S, Dewanjee S, et al. The preventive role of green tea catechins from obesity and related disorders especially hypercholesterolemia and hyperglycemia. J Trans Med. 2015;79(13):2-9. doi: 10.1186/s12967-015-0436-х.

82. Reto M, Almeida C, Rocha J, Sepodes B, Figueira ME. Green Tea (Camellia sinensis): Hypocholesterolemic effects in humans and antiinflammatory effects in animals. Food Nutr Sci. 2014;5(22):21852194.

83. Lamothe S, Azimy N, Bazinet L, Couillardc C, Britten M. Interaction of green tea polyphenols with dairy matrices in a simulated gastrointestinal environment. Food Funct. 2014;5(10):2621-2631. doi: $10.1039 / \mathrm{c} 4$ fo00203b

84. Ghasi S, Nwobodo E, Ofili J0. Hypocholesterolemic effects of crude extract of leaf of Moringa oleifera Lam in high-fat diet fed Wistar rats. J Ethnopharmacol. 2000;69(1):21- 25.

85. Saluja MP, Kapil RS, Popli SP. Studies in medicinal plants: part VI. Chemical constituents of Moringa oleifera Lam. (hybrid variety) and isolation of 4-hydroxymellein. Indian J Chem. 1978;11(16B): 1044104.

86. Mehta LK, Balaraman R, Amin AH, Bafna PA, Gulati OD. Effect of fruits of Moringa oleifera on the lipid profile of normal and hypercholesterolaemic rabbits. J Ethnopharmacol. 2003;86(2-3):191195.

87. Sule OJ, Arhoghro EM. Hypocholesterolemic and hypoglycaemic effects of ethanolic extract of leaf of Moringa Oleifera Lam in high fat diet fed Wistar rats. J Med Biol Sci Res. 2016;2(6):109-113.

88. Raida K, Nizar A, Barakat S. The Effect of moringa oleifera aqueous extract in rabbits fed with high cholesterol diet. Eur J Sci Res. 2008;22(3):352-360.

89. Jain PG, Patil DS, Haswani NG, Girase MV, Surana AJ. Hypolipidemic activity of Moringa oleifera Lam., Moringaceae, on high fat diet induced hyperlipidemia in albino rats. Braz J Pharmaco. 2010;20(6):969-973. 
90. Rajanandh MG, Satishkumar MN, Elango K, Suresh B. Moringa oleifera Lam. A herbal medicine for hyperlipidemia: A preclinical Report. Asian Pac J Trop Dis. 2012;2(S2):S790-S795.

91. Kumar KP, Mandapaka RT. Effect of moringa oleifera on blood glucose, LDL levels in types II diabetic obese people. Innov J Med Health Sci. 2013;3(1):23 - 25. 